\title{
SARKADI NAGY EMESE: A KERESZTÉNY MÚZEUM KÖZÉPKORI MAGYARORSZÁGI, A NÉMET ÉS OSZTRÁK TARTOMÁNYOKBÓL SZÁRMAZÓ TÁRGYAINAK ONLINE KATALÓGUSA. ESZTERGOM 2017
}

Igazat adhatunk az Új Magyar Sion korabeli szerzőjének, miszerint a Simor János hercegprímás alapította érseki képtár 1875. október 12-i megnyitása „egykoron Esztergom városának évkönyveiben nevezetes momentum gyanánt fog szerepelni". ${ }^{1}$ A múzeum létrehozása és közel százötven éves fennállásának története valóban meghatározó a magyarországi muzeológiában. Ennek a történetnek, amelynek sok-sok szálból álló fonala a 19. századi gyűjtést és múzeumalapítást meghatározó koncepcióktól a későbbi szerzeményeken és a gyűjtemény megismertetésén át a 21. századi, egyre specializáltabb tudományos feldolgozásig fut, egyik legfrissebb momentuma a 2017 októberében nyilvánossá tett online katalógus. ${ }^{2}$ Sarkadi Nagy Emese munkája a múzeum középkori (és kora újkori) magyarországi, német és osztrák tartományokból származó műkincseit, szobrokat, önálló képeket, oltártöredékeket emel a kutatás tárgyává.

Az esztergomi múzeum fent említett muzeológiai jelentősége igen sokrétű. Egyik tényezője kétség kívül az, hogy hazai területen az első alkalommal vált intézményes formában nyilvánossá tudós egyházfő által létrehozott képzőművészeti gyűjtemény, amely az 1880-as évek második felétől az egyházi felszerelésekkel kiegészítve museum christianum-má bővült. ${ }^{3}$ Másrészt a Simor-féle museum, amely hivatalosan 1926-ban Ipolyi igen gazdag tárgyanyagával - magyarországi viszonylatban a leggazdagabb középkori és kora újkori gyưjiteménnyel - és Csernoch János esztergomi érsek 20. század első évtizedeire tehető szerzeményeivel számottevően gazdagodott, intézményi és gyưjteményi egységben tanúskodhatott és tanúskodhat ma is a 15-16. századi mükincsek együttes jelenlétéről, azaz a 19. század egyik jellegzetes gyưjitési koncepciójáról.
Noha mindhárom egyházfő gyưjtött mást is, többek között iparművészeti tárgyakat, valamint manierista, barokk és 19. századi darabokat is szereztek, Simor pedig különösen vonzódott a középkori esztétikai és tartalmi kánonhoz visszaforduló kortárs nazarénus festészethez, az online katalógus szempontjából csak a korai múvészetre vonatkozó tevékenységükről szólunk röviden. Nagyjából azonos időszakban, a 19. század második felében Simor és Ipolyi csaknem azonos szándék és eszmeiség mentén alakította ki középkori, kora újkori gyűjteményét. Tevékenységüket már egyfajta szerzeményezési stratégia jellemezte, a preferenciáik valóságosan kitapinthatók, tudományos megalapozottság, de legalábbis elképzelés rejlett a hátterükben. Simor és Ipolyi érdeklődésnek fókusza, sőt hosszú távú célja volt: gyüjteni a keresztény múlt európai múkincseit, megmenteni, feltárni, megőrizni a magyar középkor emlékeit, és ízlésformáló, nevelő példaként állítani a közönség elé. ${ }^{4} \mathrm{Ez}$ a fajta érdeklődés és gyüjtőtevékenység Magyarországon elsősorban a magasabb hivatalokat betöltő, igen művelt, tudós egyházfö-generációhoz köthető. Simor és Ipolyi mellett többek között a hasonló attitüddel rendelkező, egymás között is jó ismeretséget ápoló Császka György (1826-1904) kalocsai érsek, Bubics Zsigmond (1821-1907) kassai püspök és Dankó József Károly (1829-1895) pozsonyi prépost tevékenysége tekinthető meghatározónak; utóbbiak egyenetlenebb színvonalú, de jeles vagy múvészettörténeti szempontból fontos középkori és kora újkori darabokat is tartalmazó gyúijteménye azonban javarészt szétszóródott. ${ }^{5}$ Múpártolásuk és munkásságuk szellemi háttere a korabeli európai tendenciákhoz, különösen kölni és minden bizonnyal bécsi, Bécs környéki példákhoz igazodott, 
amelyek a középkori és kora újkori, 14-16. századi német, németalföldi, közép-európai és itáliai festészet megítélésének pozitív fordulatáról tanúskodtak. A nyugati filozófiai áramlatok, Hegel, Friedrich Schlegel, később Heinrich Gustav Hotho és Carl Schnaase gondolatisága, amely a középkori müvészet értelmezésében és értékelésében a történetiségnek különösen fontos szerepet juttatott, néhány lépéssel eljutva a nemzeti múlt felkutatásának igényéhez, összekapcsolódott a keresztény vallás bensőségességének romantikus felerősödésével, a szóban forgó korszakot a vallásos érzület legkifejezőbb és legtisztább közvetítőjének tekintve. ${ }^{6}$ Igy a 14-16. századi művészet mind esztétikai, mind tartalmi példává vált, és egyik célpontja lett a 19. században egyre inkább rétegződő történeti stúdiumoknak. Magyarországon is megszaporodtak a történeti érdeklődésű társaságok és kiadványok, felértékelődtek a történeti emlékek - levéltári gyüjteményegységek, hagyatékok, épített emlékek, képző- és iparmúvészeti tárgycsoportok -, és különös lendülettel indult meg ezek feldolgozása. Mindezekben a fent említett egyházfők aktív és meghatározó szerepet vállaltak. Sokrétü tevékenységük, a korabeli szellemi kultúrában betöltött szerepük részletes feltérképezése és a feltáratlan összefüggések meghatározása ehelyütt azonban nem lehet feladatunk.

Ez a sommás áttekintés itt azzal a történeti ténynyel nyeri el létjogosultságát, hogy a közelmúltban elérhetővé tett online katalógus tárgyanyaga e szemlélet eredményeképpen lehet ma múzeumi kincsünk, az egyházfők jó szemmel és felkészültséggel való válogatásának köszönhetően pedig a közép-európai középkori és kora reneszánsz müvészet kutatásának megkerülhetetlen bázisává válhatott. Ez utóbbi vonatkozásban a most megjelentetett katalógus több szempontból is mérföldkőnek tekinthető. Elsősorban abban a tekintetben, hogy első alkalommal dolgozza fel szisztematikusan és teljességében a múzeum középkori és kora újkori közép- és közép-nyugat-európai mükincseit, ezáltal a maga gyüjteményi egységében láttatva és megközelítve a fent vázolt gyüjtéskoncepció eredményeképpen kialakult tárgy-együttest.

A katalógus jellegének meghatározása első benyomásra zavarba ejt, mert - noha a részletek még kibontás előtt állnak, bíztatva egy jövőbeni szakkatalógust elkészítésére - szerencsés módon felülmúlja egy múzeumi checklist vagy summary catalogue jellegét. A tárgyakra vonatkozó alapadatokon túl, mint az attribúció és a keltezés, az állapotot vázoló megjegyzések, az ismert proveniencia, az aktualizált bibliográfia, kiállítástörténet és restaurálástörténet, amelyek gondos összeírása és a legújabb szakirodalom, illetve saját kutatói ál- láspont szerinti meghatározása egy gyüjteményi egység teljességre törekvő megközelítésénél már önmagában is nagyon fontos eredmény, a katalógus mélyebb és részletesebb ismereteket kínál. Ilyenek az egyes oltártábláknak az egykori oltárművekben való helyének kijelölése - itt meg kell jegyezni a leírás példaértékű precizitását, amely a hétköznapi oldal, ünnepi oldal, szekrényfél stb. fogalmak használatával kiküszöböli a művészettörténet-írásban a mindkét oldalán díszített oltártáblák esetében is meggyökeresedett előoldal-hátoldal leírás problematikáját -, a friss stíluskritikai meghatározások, az egy-egy tárgyon fennmaradt feliratok pontosítása vagy a gyüjteménytörténeti kutatásokkal megfeleltethetô új eredmények beemelése. Ez utóbbiak közül legfontosabb a vonatkozó tárgyak azonosítása az Ipolyi-gyüjtemény közelmúltban publikált, eddigi legteljesebb jegyzékének tételeivel, amely mind világosabbá teszi a váradi püspök gyüjteményének egykori összetételéről való ismereteinket. ${ }^{7}$ Az említett alapadatok együttese, amely a feldolgozásnak már ebben a fázisában is sok jelentős és érdekes újdonsággal kecsegteti az érdeklődőt biztos és hiteles kiindulópontja a további, részletes kutatásnak, mélyfúrásoknak. Ehhez járul hozzá az információk mellett a teljes tárgyanyag jó minőségű reprodukcióinak közlése - a felvételeket Mudrák Attila készítette -, amely magában foglalja a szétfürészelt és az önálló táblák hátoldalának közlését is. Míg az alapadatok és a reprodukciók közlése a gyüjtemény széles körben ismert, kimagasló művészettörténeti ranggal bíró darabjai esetében - mint például a garamszentbenedeki Úrkoporsó vagy M.S. Mester selmecbányai oltárának enigmatikus szépségű táblái - sem elhanyagolható, hiszen egy teljesen friss állapotot rögzít, addig számos olyan tárgy vált a katalógus által elérhetővé, amelyek nem szerepeltek kiállításon, eddigi közléseik csupán néhány adatot és alkalmanként kisméretü, fekete-fehér fotót tartalmaztak, vagy ezek híján csak azok ismerhették, akik maguk is bejáratosak voltak a múzeum raktáraiba. Ebből a szempontból a Keresztény Múzeum a most megjelent online katalógussal érdemben követi azt a nemzetközi tendenciát, amely egy-egy gyüjtemény teljes körü megismertetésére, nem kvalitás szerint válogató, hanem történeti hangsúlyú feldolgozásra törekszik.

Egy gyűjteményi egységet bemutatni kívánó katalógus, legyen az bármilyen mélységü is - a kérdéskörök sokrétüsége okán - széleskörü módszertani megközelítést, mérlegelést, alapvető döntéseket igényel. Ennek első és egyik legmeghatározóbb szegmense a feldolgozni kívánt tárgyak csoportjának meghatározása. A Sarkadi Nagy-féle katalógus ebben a kérdésben a magyarországi művészettör- 


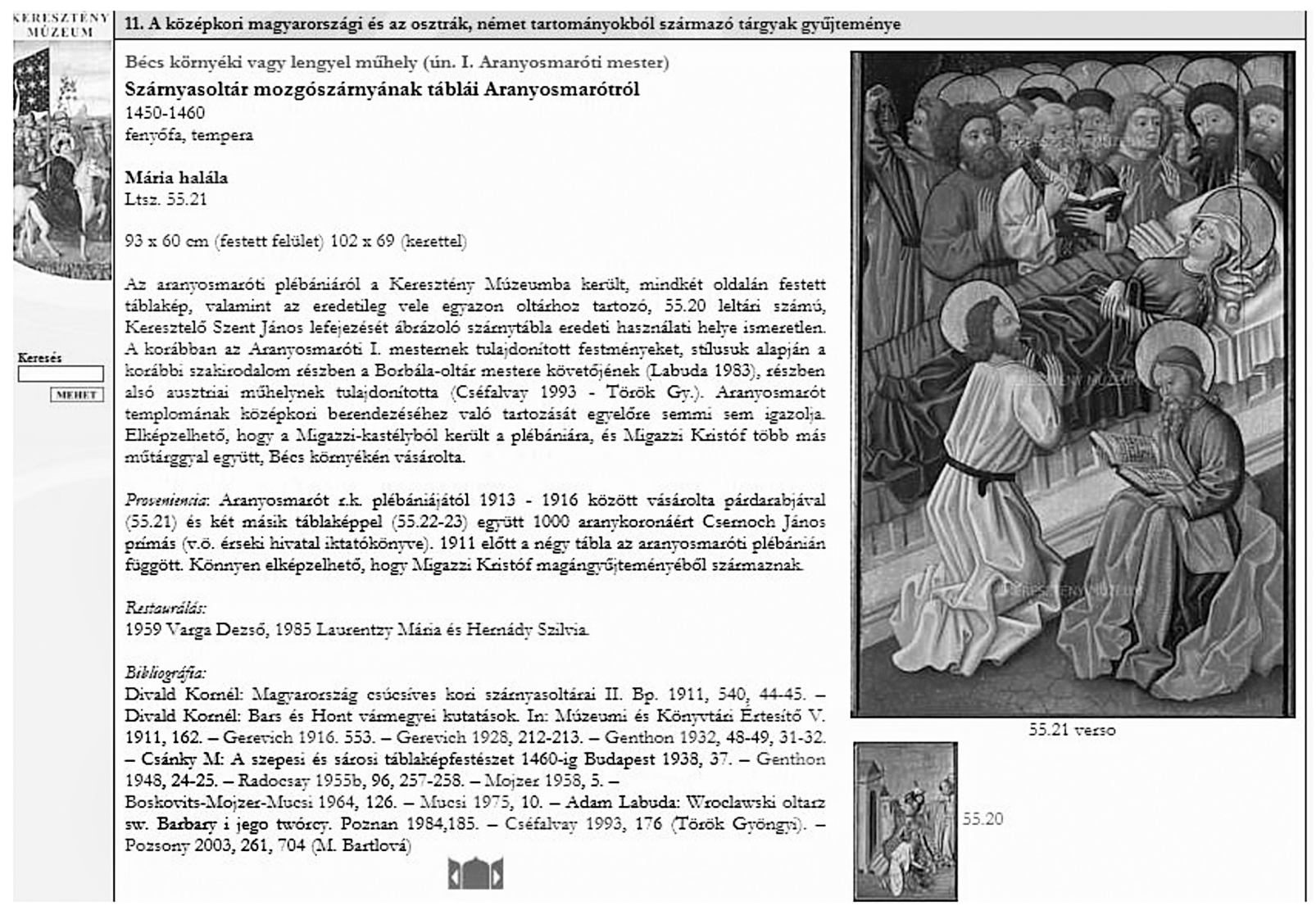

1. Bécs környéki vagy lengyel műhely (ún. I. Aranyosmaróti Mester), Mária halála. Részlet az esztergomi online katalógusból

ténet kutatásban úttörő szerepet vállalt, követendő példát állítva a hasonló gyüjtemények megközelítéséhez, ugyanis első alkalommal tárgyalja egy egységben a magyar, illetve az osztrák és német területekre lokalizálható vagy onnan származó múveket. Ennek oka abban ragadható meg, hogy Közép- és Közép-Nyugat-Európa - ide sorolva az osztrák tartományokat, lengyel és cseh területeket, valamint a német területek déli, dél-keleti részét is - középkori és kora újkori művészete rendkívül gazdagon és ezernyi szállal fonódik egymásba. A vándorművészek és a korabeli, ikonográfiai, formai és technikai mintákkal dolgozó, olykor különböző területekről érkező segédeket, tanoncokat alkalmazó műhelygyakorlat az összefüggések olykor kibonthatatlannak tűnő szövedékét teremtette meg. Ebből a szempontból az esztergomi gyüjtemény összetétele, nehézségei ellenére, kedvező forrást nyújt a feldolgozást illetően, hiszen szinte rákényszeríti a kutatót egy-egy problematikus és összetett kérdés újragondolására, ez esetben például a bécsi vagy Bécs környéki 15. századi festészeti műhelyek körvonalazására, vagy a cseh, német, ausztriai festészetnek a régi magyar múvészetre gyakorolt hatása pontosabb meghatározására. A katalógus szerzője, tisztán látva e kapcsolatok és hatások összetettségét, különös óvatossággal és körültekintéssel állapította meg az emlékek lokalizálást. A teljes tárgyanyagot tekintve csupán két helyen maradt ránk konkrét mesternév vagy jelzés Kolozsvári Tamás Kálvária-oltárán (19. századi másolatban, ltsz. 54.3-10) és MS Mester oltárának Feltámadás-tábláján (ltsz. 55.104). Egy-egy körvonalazott, szükségnévvel ellátott mester körébe vagy műhelyébe sorolás mellett - ahol akkurátusabb meghatározásra nem volt lehetőség - az ismeretlen mestereket tartomány vagy ország / országrészek szerint lokalizálta, illetve a fent említett, esetleg később még pontosabb műhely-meghatározásokkal kecsegtető vagy éppen az összetettségük miatt pontosabb besorolással nem illethető daraboknál éles szemmel alkalmazta a pl. Bécsi tanultságú festő vagy Bajor tanultságú festő körülírást. E szerteágazó kapcsolatok egyik beszédes példáját adják többek között az egykor Aranyosmaróti I. és Aranyosmaróti II. Mesternek tulajdonított, korábban rendre a magyar festészet tárgykörébe sorolt, az aranyosmaróti plébániáról Esztergomba került oltártáblák. Szent Jakab és Szent János mártíromságát, valamint a Bemutatás a templomban és Mária halála jeleneteket ábrázoló szárnyasoltár-töredékeket Sarkadi Nagy a képeken szembetűnő, és már korábban is körvonalazott osztrák és lengyel (első- 


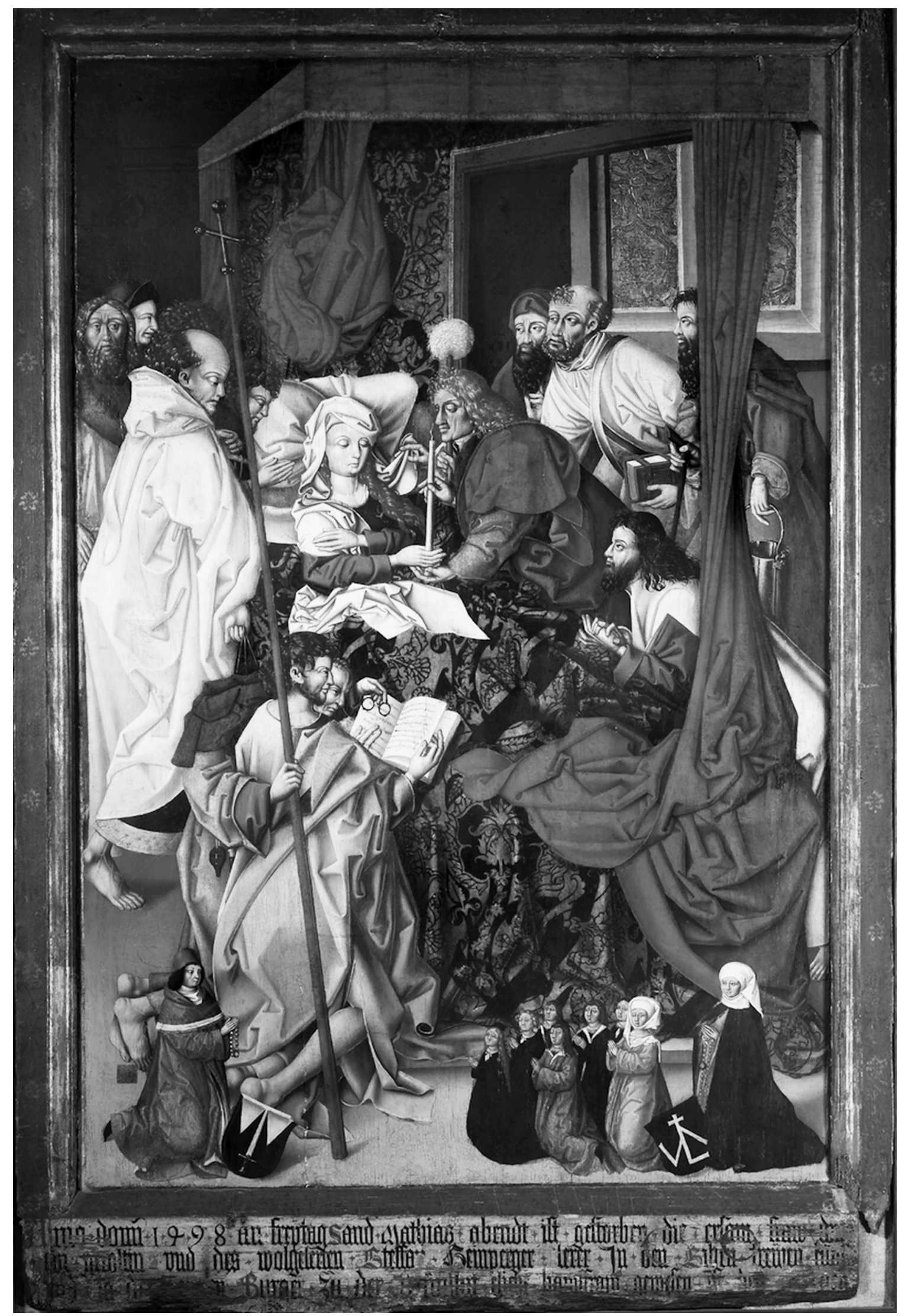

2. Bécsújhelyi mühely, Mária halála. Stephan Geinperger feleségének epitáfiuma, 1498 után, fatábla, tempera, $156 \times 104 \mathrm{~cm}$ (eredeti kerettel: $180 \times 120$ cm). Esztergom, Keresztény Múzeum, ltsz. 56.509. Fotó: Mudrák Attila 
sorban sziléziai) igazodás figyelembevételével Bécs környéki vagy lengyel mühely meghatározással illette. A két mártíromság jeleneten talán valamivel határozottabb a nyugati hatás, a fiziognómia, a kezek, lábfejek markáns kialakítása, a mozdulatok hangsúlya a század negyvenes-ötvenes éveinek osztrák festészetével is összefüggésbe hozható. (Az egykori oltár Mária halála jelenete véleményem szerint kompozíciós összefüggést mutat a Szépmüvészeti Múzeum Dél-Tirolba lokalizált, a szakirodalomban 1480-1490-re keltezett, de talán valamivel korábbi, azonos témájú képével. ${ }^{8}$ ) A II. Mester Királyok imádása és $\mathrm{A}$ tizenkét éves Jézus bemutatása a templomban oltártábláin erősebb nyugati orientáltságot, Hans Pleydenwurffnak feltehetően bécsi mesteren / mühelyen keresztül érkező, jól körvonalazható hatását hangsúlyozva a szerző Bécsi tanultságú mesterként határozza meg képek készítőjét.

A térbeli mellett az időbeli körülhatárolás válogatja ki alapvetően a feldolgozni kívánt tárgyak csoportját. A katalógusban szereplő művek készítési ideje a 12. századtól a 16. század első harmadáig ívelő időszakot fog át. Legkorábbi a kölni románkori szobrászat egyik éteri finomságú müve, a Kenetet vivő asszony szobra (ltsz. 56.826), legkésőbbi darabjai már a reneszánsz stílusjegyeit hordozzák: az id. Lucas Cranach müvészetéhez köthető képek, így az 1530 utánra keltezett, de a festés habitusából ítélve talán a 16. század közepénél nem korábbi Pihenő Szent Család (ltsz. 56.453) és a műhelynek tulajdonított Szent Kristóf (ltsz. 55.395), vagy az Albrecht Altdorfer követőjétől való Kálvária (ltsz. 56.471) már az északi reneszánsz egy-egy emléke. A múzeum vonatkozó német tárgyai közül nem szerepel azonban a katalógusban a korábban 1520-ra keltezett, ${ }^{9}$ de talán bő évtizeddel későbbi, sokalakos Kálváriakép (ltsz. 56.462), noha időben és párhuzamba állítva a katalógus néhány más tárgyával, joggal kereshetjük. Részben azért, mert a fentebb vázolt gyüjtési koncepcióba maradéktalanul illeszkedik, Simor egyik több ízben emlegetett szerzeménye volt, részben mert a reneszánsz motívumok (pl. a bal oldali építészeti részlet) és a helyenként manierisztikus festésmód ellenére (a kép későbbi átfestései külön szemrevételezést igényelnének) kompozíciójában a 15. századi észak-német, elsősorban vesztfáliai ábrázolásokat követi, amelyek Hans Memling lübecki oltárával (Lübeck, St.-Annen Museum, 1491) is öszszefüggésbe hozhatók. Ha a katalógus időbeli lezárását a Cranach utáni Szent Család, illetve egy délnémet Ecce homo (ltsz. 56.736) jelenthetné - utóbbi véleményem szerint a 16 . század első negyedénél későbbi, a Dürer-metszetet követő atletikus Krisztus-testnek és az arcnak a sfumatós fény-árnyék kezelés adta plaszticitása (számomra sajnos nem is- meretes, hogy képen van-e és ha igen, milyen mértékü későbbi átfestés), valamint a fülledtebb színvilág (amit ugyan a megsárgult lakkréteg is okozhat) inkább a harmincas évekre vagy későbbre helyezi a festményt-, a Kálvária megférne a többi itt tárgyalt mü között.

Az elsődleges kutatói döntések után lássunk néhányat a katalógus részleteiben is jelentős újdonságaiból, amelyek első megközelítésben egy-egy vizsgálati módszerhez köthetők. A felirattal rendelkező darabok epigráfiai (felül)vizsgálata több esetben is a mütárgy történetének egészét befolyásoló, további kutatásra sarkalló eredményt hozott. Ilyen példa a bécsújhelyi múhelynek tulajdonított, Mária halálát ábrázoló nagyméretü epitáfiumkép (ltsz. 56.509) feliratának helyesbítése, amely az eddig Heimpergerként olvasott részletet Geinpergerként pontosította. A képpel kapcsolatban most meghatározott személy, az orvosi tanulmányokat végzett dr. Stefan Geinperger 1494-ben, 1499-ben, illetve 1505-1507 között Bécsújhely polgármestere volt. ${ }^{10}$ Számos forrással jól körvonalazható tevékenysége, társadalmi szerepe és családtörténete minden bizonnyal sok fontos és érdekes adalékkal fog szolgálni az epitáfium és Bécsújhely 15. század végi történetéhez. ${ }^{11}$ Másik példaként álljon itt egy az Ipolyi-gyüjteményből származó szárnyasoltár bal oldali mozgószárnya, amelyen a Szent Margit társaságában ábrázolt donátor alakját sikerült a felirat, „(a)bt • her • Assem • cu • Sa(n)t Salfatur" helyes kiolvasásával és elemzésével meghatározni. A felirat a bajor területen található Griesbach Sankt Salvator elnevezésű premontrei kolostorára utal, akinek apátja 1480 és 1484 között Erasmus (Assem) Pöchinger volt. Ez a felfedezés megerősítette a mindkét oldalán díszített oltártábla stiláris alapon első ízben „megpedzett” bajor eredetét. ${ }^{12}$ Sarkadi Nagy más, München és Augsburg környékére lokalizálható, egykori Ipolyi-gyüjteménybeli művek alapján azt vetette fel, hogy a tudós püspök feltehetően erről a környékről is vásárolhatott. ${ }^{13}$ A felvetés nem csak az azonos területre lokalizálható tárgyak együttese miatt érdekes, hanem azért is, mert a mai ismereteink szerint Ipolyi külföldi vásárlásai során általában több darabot, alkalmanként összefüggő tárgy-együttest választott; egykori gyüjteményének minden bizonnyal jó néhány forrása azonban még meghatározásra vár.

Ennek egyik, a most publikált mütárgyanyagot érintő fontos és igen sok kérdést megpendítő példája az úgynevezett Blasius Höfel-gyüjteményre visszavezethető szerzeményezés. Theodor von Frimmel 1914-ben teljességében közzétett egy 1839es, negyvenkét tételt (tételenként azonban javarészt több darabot) kínáló árverési katalógust, amelynek 
címlapján ceruzával írva a "Höffel” nevet rögzítették. ${ }^{14}$ Az utólagosan feljegyzett tulajdonost (?) Frimmel és a müvészettörténeti irodalom feltételesen Blasius Höfel (1792-1863) metsző, metszetkiadó és xilográfussal azonosította, aki a korabeli említések szerint mintegy száz, javarészt bécsújhelyi otthonának környékéről gyüjtött mükincset, föképp festményt birtokolt. Frimmel szerint a gyüjteményt 1839-ben id. Karl Josepf Leman (1785-1847) bécsi gyárosnak adta el, aki a feltételezések szerint ennek egy részét, többségében feltehetően középkori vagy kora újkori képeket, bocsátotta áruba 1839-ben a fent említett katalógusban, a gyüjtemény többi részét talán fia örökölte. Ha a korabeli forrásoknak hitelt adhatunk, akkor az egyik legnagyobb, középkorra fókuszáló mütárgy-együttes lehetett Höfelé, amely talán nem volt ismeretlen a hasonló preferenciák mentén gyüjtők számára. E gyưjtemény azonban és annak számos, tisztázatlan szálat rejtő históriája máig homályba burkolózik, és csak reméljük az olyan, még nem kutatott vagy rendszerezett forrásanyagok létezését, amelyek e kérdések megválaszolásában segítségünkre lehetnek. ${ }^{15}$ Mindez a magyarországi müvészettörténet-kutatás számára többek között azért is lenne különösen fontos, mivel Pigler Andor 1932-ben az 1839-es árverési katalógus tizenkét tételét feleltette meg esztergomi darabokkal, köztük önállóként szereplő képeket, összetartozó oltártáblákat, és részben helyes, részben téves összeállításban listázott oltárműveket. ${ }^{16}$ A képek Ipolyi gyüjteményéből kerültek Esztergomba, aki talán az ifjabb Lemanntól (feltételezve, hogy az esztergomi darabok nem keltek el 1839ben) vagy egy következő tulajdonostól vásárolhatta (akinek azonban az 1839-es árverésen egy nagyobb tárgyegyüttest, azaz legalább a ma Esztergomban található „Höfel”-képek csoportját meg kellett vennie). E tárgyak mindegyike az online katalógus tárgykörébe tartozik, amelyek között néhány szoros és fontos összefüggést - többek között egyes összetartozó oltárrészek kapcsolatát - Sarkadi Nagy ismert fel a katalógust előkészítő munka során. Ezek közül az a kitűnő rekonstrukciós felvetés a legjelentősebb, amely a Pigler meghatározásával Evagationes spiritus, azaz a Lélek tévelygései címmel ismert képhez kapcsolódik (ltsz. 56.495). A Pigler által a triptichon bal oldali mozgószárnyaként meghatározott kép, amelynek jobb szárnyán az általa ismertetett analógiákból kiindulva a Krisztus feszülete alatt helyesen imádkozó ember alakja lehetett, a nyitott oltárka pedig az Olajfák hegyétől a Szen- vedéstörténet egyes jeleneteit mutathatta be, Sarkadi Nagy kutatásainak köszönhetően most - ha csak töredékesen is - de megtalálta eredeti kontextusát. A szerző a Krisztus életének jeleneteit bemutató predella (ltsz. 55.110) bal oldali mozgószárnyaként azonosította a táblát, amely által a kép funkciója és tartalma is meghatározhatóvá válik és kiteljesedik. A rossz és a jó imádság, a főbünökhöz vezető földi javak béklyója és a hit tisztaságának különbözőségére figyelmeztető ábrázolások tartalmi teljességüket az Ige testté válása, Krisztus földi szenvedéstörténete és mennybemenetele kontextusában nyerik el. A rekonstrukciót megerősíti a predella és az Evagationes spiritus tábla technikai jellegzetességeinek alapos vizsgálata, a stiláris, valamint az ikonográfiai összefüggések meghatározása, valamint a gyüjtéstörténeti megközelítés: hiszen a predella és a tábla egyaránt szerepelt az 1839-es aukción, így talán az egykori Höfel-gyüjteményben is, noha az árverésre már nem az eredeti formájában vették fel.

A katalógussal nyilvánossá tett kiváló, eredményes munka művészettörténeti jelentőségén túl szót kell ejtenünk annak megjelenési formájáról is. Noha a mai napig ragaszkodunk a könyvek kézzel fogható valóságához, a leírt és a nyomtatás által papírra „vésett” szó súlyához, az egyre inkább terjedő digitális publikálás - nem egy nagy amerikai és európai múzeum szakkatalógusait, sőt, alkalmanként kiállítási katalógusait is ebben a formában közli - számos előnnyel jár. Többek között javítható, nem szab szigorú terjedelmi korlátot sem a leírt szöveg, sem pedig, és talán ez még fontosabb, a közlésre szánt reprodukciók tekintetében, könnyen és gyorsan elérhető, illeszkedik a múzeumi gyüjteményekkel szemben elvárt digitalizációs stratégiákba, valamint költséghatékony, mind az előállítást, mind pedig a hozzáférhetőséget tekintve. Az esztergomi katalógus - néhány kisebb, de biztosan fejleszthető hiányosságot leszámítva - remekül kihasználja az online publikáció lehetőségeit, és remélhetőleg példaként áll majd a magyar múzeumok jövőbeni, hasonló jellegü munkáinak közléséhez. Ma már nemcsak a szakma, de az érdeklődő közönség is nagymértékben használja tájékozódás- és információgyüjtésképpen a digitális világot, amely ebben az esetben azt a keresztény európai kultúrát megismertetni kívánó és ízlésformáló szándékot is közvetítheti áttételesen, amelyet egykoron Simor és Ipolyi a museum christianum gondolata egyik alaptételének tartott.

Varga Ágota 


\section{JEGYZETEK}

1 Maszlaghy Ferenc: Az esztergomi Érseki Képtár. Új Magyar Sion 7. 1876, 30.

2 http://www.keresztenymuzeum.hu/collections. php?mode=intro\&cid=11\&vt=. A katalógust előkészítő kutatómunkát az OTKA támogatta. Az online katalógus 2018 nyarán, e recenzió kéziratának lezárását követően Opus Mirabile-díjban részesült. Nem sokkal ez után pedig megjelent a Szerző szélesebb közönségnek szánt kalauza a múzeum vonatkozó gyüjteményegységéről, amely az online katalógus számos új eredményét is közli. Sarkadi Nagy Emese: Mühelytitkok. Rendhagyó kalauz a Keresztény Múzeum középkori magyarországi, valamint a német és osztrák tartományokból származó műalkotásainak gyüjteményéhez. / Workshop secrets. A Unique Guide to the Christian Museum's Collection of Medieval Works from Hungary and the German and Austrian Territories. Esztergom 2018, 232 lap. A kötet teljes egészében kétnyelvü és színes képekkel gazdagon illusztrált. A könyvet Mikó Árpád mutatta be a budapesti Párbeszéd Házában 2018. június 18-án.

3 Noha nem hagyhatjuk figyelmen kívül Pyrker János velencei pátriárka és egri érsek 1836-ban tett adományát a Nemzeti Múzeumnak, valamint Ipolyi Arnold 1872-es nagylelkű felajánlását az Országos Képtár számára, mindkettő egy már meglévő múzeumi intézmény példaértékű gyarapítását, nem pedig önálló alapítást jelentett. Lásd Harasztiné Takács Marianna: A Pyrker képtár a Szépművészeti Múzeumban. In: Hölvényi György szerk.: Pyrker emlékkönyv. Budapest 1987, 205-301; Dóra Sallay: The Sienese Paintings in Hungary. A History of Collecting, Conservation and Previous Research. In: Uo": Corpus of Sienese Paintings in Hungary 1420-1510. Florence 2015, 13-67, 30. A polgári gyüjtésben Joseph Daniel Böhm (1794-1865) szobrász, érmekészítő bécsi gyűjteményének összetétele jelzi a művész komoly érdeklődését a középkori emlékek iránt.

4 Ehhez természetesen az itáliai művészet emlékeinek gyűjtése is hozzá tartozik, de az online katalógus tárgyköre miatt erről külön nem szólunk. Az itáliai művekkel kapcsolatban lásd Sallay i. m. (3. j.) 13-67.

5 Ezen egyházfők műpártoló tevékenységének részletes kutatásával jelen ismertető szerzője foglalkozik doktori témájának keretében.

6 A témáról összefoglalóan lásd Bernhard Ridderbros és Wessel Krul tanulmányait: From Waagen to Friedländer; Realism, Renaissance and Nationalism. In: Bernhard Ridderbros, Anne van Bueren, Henk van Veen Eds.: Early Netherlandish Paintings. Rediscovery, Reception, and Research. Los Angeles 2005, 218-251, 252-289; Frank Günter Zehnder hrsg.: Lust und Verlust Kölner Sammler zwischen Trikolore und Preußenadler (Ausstellungskatalog, Joseph-Haubrich-Kunsthalle, Köln 1995-96), Köln 1995. A magyarországi gyűjtők szemléletét formáló filozófiai, történetfilozófiai hatások, a tevékenységüket inspiráló európai gyűjtők, gyűjtemények, tudós társaságok, folyóiratok stb. ismertetésére már kitűnő részeredményekkel büszkélkedhet a magyar múvészettörténeti szakirodalom. Az összefüggések részletes vizsgálata azonban még jövőbeni feladatunk.

$7 \mathrm{Az}$ újabban előkerült leltárakat lásd Lakatos-Balla Attila: Ipolyi Arnold püspök hagyatéka Nagyváradon. (Miscellanea Historica Varadinensia, III.) Nagyvárad 2012. Lakatos-Balla négy különböző, 1886 és 1919 között írt gyüjteményi listát közöl. Ezek közül Sarkadi Nagy az azonosításra leginkább alkalmas, 1916-ban felvett leltárt használta (Lakatos-Balla 274-296).

8 Urbach Zsuzsa In: Ildikó Ember - Imre Takács eds.: Old Masters' Gallery. Summary Catalogue, Volume 3. German, Austrian, Bohemian and British Paintings. Szépművészeti Múzeum, Budapest 2003, 126.

9 Boskovits Miklós - Mojzer Miklós - Mucsi András: Az esztergomi Keresztény Múzeum képtára. Budapest 1964, 160-161.

10 Lásd pl. Martin Scheutz, Kurt Schmutzer, Stefan Spevak, Gabriele Stöger Hrsg., Einleitung von Albert Müller: Wiener Neustadter Handwerksordnungen (1432 bis Mitte des 16. Jahrhundert). Wien-Köln-Weimar 1996, 115, 121.

11 Sarkadi Nagy Emese és Majorossy Judit a közeljövőben publikálja a témában felkutatott új ismereteket.

12 A képet legutóbb bemutató katalógus (BoskovitsMojzer-Mucsi 1964, 140, 142, 229. sz.) magyarországi eredetet feltételezett, a donátor alakját pedig a Bars megyei lekéri bencés apátsággal hozta összefüggésbe. A megrendelőről Sarkadi Nagy Emese és Majorossy Judit közös tanulmánya megjelenés alatt áll.

13 Sarkadi Nagy Emese előadása a katalógus bemutatóján 2017. október 14-én, Esztergomban.

14 Theodor von Frimmel: Lexikon der Wiener Gemäldesammlungen. München 1913-1914, Bd 2. 1914, 172-180, 519-520.

15 Néhány, a művészettörténeti irodalom által eddig mellőzött említés folyamatban lévő rendszerezése talán már előrelépést fog jelenteni ebben a kérdésben, illetve a tervezett további kutatás remélhetőleg közelebb visz majd a Höfel-gyüjtemény - és története - pontosabb körülírásához. Ehelyütt nincs alkalmunk felsorolni a gyüjteménnyel kapcsolatos említéseket, felvetéseket, irodalmat.

16 Pigler Andor: „Evagationes spiritus”. (Egy képmagyarázat és adatok az esztergomi Keresztény Múzeum festményeinek történetéhez). Archaeologiai Értesítő 46. 1932-1933 [1934], 121-136. A Verzeichnis további eddig (biztosan) azonosított darabjai: egy 15. századi Zwölfboten-oltár táblái az apostolok mártíromságával (a katalógusban említett tíz táblából nyolc Budapest, Szépmúvészeti Múzeum; Frankfurt, Städel; Bécs, Museum Schottenstift, az egykori oltár két további táblája a pozsonyi Szent Márton-dómban [nem a Höfel-gyüjteményből]); Waloch-epitáfium, Prága, Národni Galerie. 